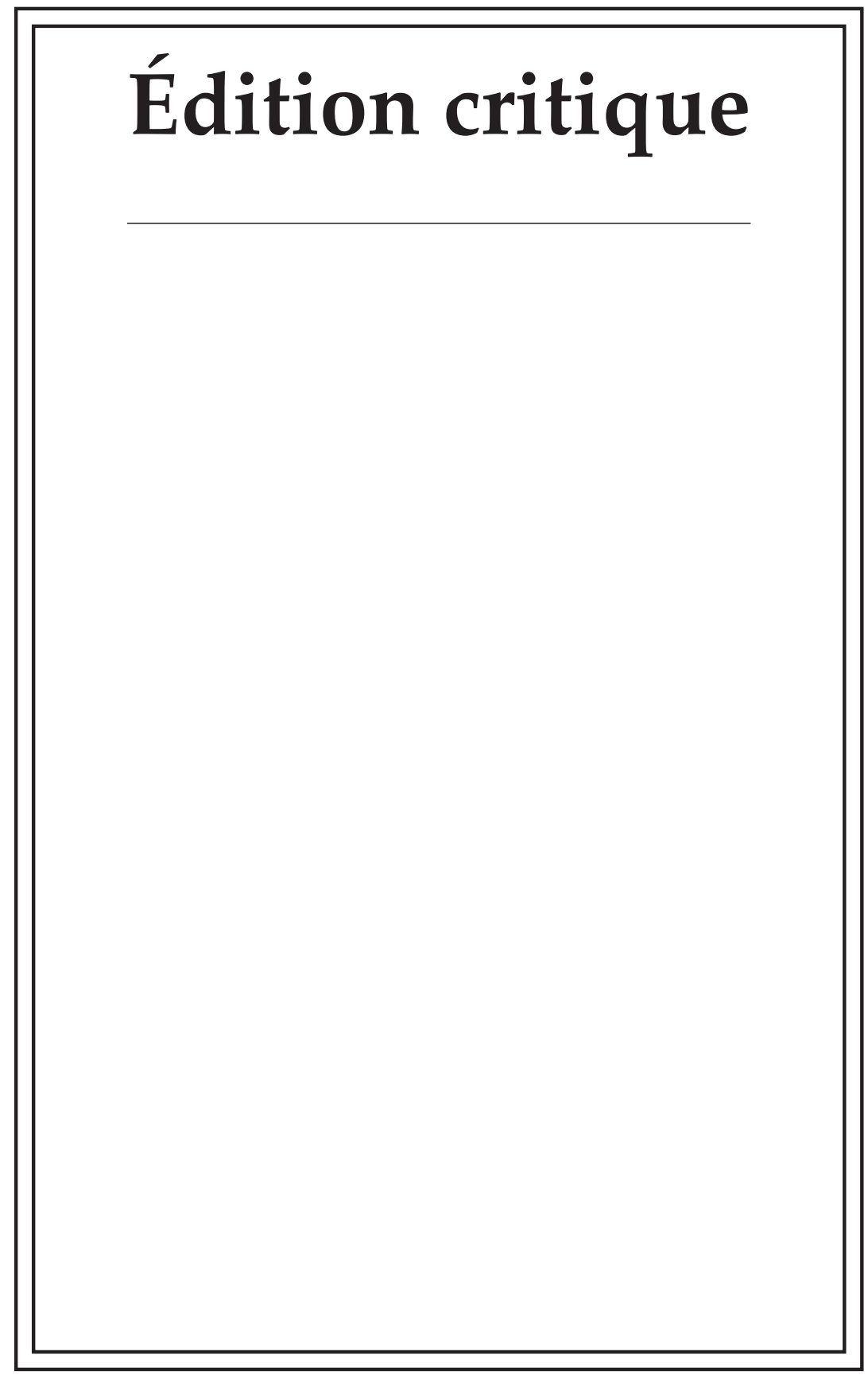


Andrei S. Slutskij

St Petersburg

\section{EARLY SLAVONIC VERSIONS OF THE LITURGY OF THE PRESANCTIFIED GIFTS}

\section{PREFACE}

The Liturgy of the Presanctified Gifts has a special place in the rite of the Orthodox Church. Presently, this service of great beauty is performed only during Great Lent and Holy Week. The Liturgy of the Presanctified Gifts has many features of the Lenten service, but it contains a number of specific features that are not found in other offices, customary for Orthodox liturgical practices. The origin of these liturgical elements, specific only for the service of the Presanctified Gifts, has been the subject of numerous scholarly works. Nevertheless, many issues of historical Liturgics and liturgical theology, associated with the Liturgy of the Presanctified Gifts, do not yet have generally accepted solutions. The main sources for studying the history of the Liturgy of the Presanctified Gifts are the Greek versions contained in the old Byzantine Euchologia. Along with the Greek Euchologia, the oldest Slavonic versions of this Liturgy represent important historical materials for studying the initial stages of the service of the Presanctified Gifts. The earliest surviving Slavonic service books are considerably younger than the oldest Greek Euchologia. However, due to the conservativeness of the Slavic tradition, these service books have preserved an archaic form of some of the liturgical elements that constitute the office of the Liturgy.

This publication is devoted to a historical and liturgical analysis of the oldest Slavonic versions of the Liturgy of the Presanctified Gifts. Twenty three manuscripts of the service books of the thirteenth-fourteenth centuries, which are the earliest Slavonic sources preserving the text of the Liturgy, are identified and studied in detail. These manuscripts contain the office of the Liturgy of the Presanctified Gifts that follows the oldest rules, regulating Slavonic divine services in the initial period of their history. In describing the ordinance of the Liturgy of the Presanctified Gifts, we focused on liturgical elements that were preserved in the medieval Slavic texts but have been lost in modern liturgical use. The Slavonic service books, containing the ordinance of the Lit- 
urgy of the Presanctified Gifts in its early recensions, constitute not only evidence of the formation of liturgical traditions in Slavic countries, but also an important additional source for the study of the origin and development of the Byzantine Liturgy of the Presanctified Gifts. Some of the Slavic manuscripts, while preserving the same type of description of the office of the Liturgy as the oldest Greek sources, describe the key elements of the ordinance in more detail compared to the early Greek Euchologia. This primarily applies to seventeen manuscripts of the Old Russian recension of the Presanctified Liturgy. Therefore, along with an analysis of the ordinance, this study contains a critical text edition of the Old Russian recension on the basis of all manuscripts of the text.

\section{INTRODUCTION}

The time when the Liturgy of the Presanctified Gifts appeared among Byzantine divine services, remains unknown. The earliest references to the Liturgy of the Presanctified Gifts date back to the beginning of seventh century. The Chronicon Paschale, supposedly composed in the 630s, says: "... this year, under Patriarch Sergius of Constantinople, starting in the first week of Lent of the fourth Indiction (year 615), they began to sing after 'Let my prayer arise' during the transfer of the Presanctified Gifts to the Holy Table from the skeuophylakion, after the priest says, 'According to the gift of Your Christ,' the people immediately start 'Now the Powers of Heaven invisibly with us do serve. Lo, the King of Glory enters. Lo, the mystical sacrifice is up borne, fulfilled. Let us draw near in faith and fear to become the communicants of eternal life. Alleluia." ${ }^{1}$

The most important sources for the reconstruction of the history of the Liturgy of the Presanctified Gifts are the handwritten Greek Euchologia. The ordinance of the Liturgy of the Presanctified Gifts is contained in the oldest known Barberini Euchologion 336 (8th C.), ${ }^{2}$ and the prayers contained in the Barberini 336 constitute the main part of the modern ordinance of the Liturgy of the Presanctified Gifts. Both the Barberini 336 and other old Greek manuscripts, the Sinai Euchologion 958 (9th C.) and 959 (11th C.), Sevastyanovskij Euchologion (10th C.), ${ }^{3}$ and the Euchologion of Porfirij Uspenskij (9th-10th C.), ${ }^{4}$ mention the Vespers

(1) PG 92, 989.

(2) The edition is: S. Parenti, E. Velkovska, L'eucologio Barberini gr. 336 (Roma, ${ }^{1} 1995$ [Roma, $\left.{ }^{2} 2000\right]$ ).

(3) Ms. Russian State Library Greek 474.

(4) Ms. National Library of Russia Greek 226. 
which initiate the service of the Liturgy of the Presanctified Gifts, but the texts of the prayers for the Vespers are missing. The description of the Vespers consists of a brief instruction on the readings, ${ }^{5}$ singing "Let my prayer arise...," "Lord have mercy". Then the Barberini 336 has a Prayer for the Catechumens: "God, our God, creator and maker of all things...," the Prayer for those preparing for the holy Enlightenment, "Manifest your countenance, Master...," the first Prayer of the faithful, "O God, who are great and to be praised...," the second Prayer of the faithful, "Holy Master, supremely good...," the Prayer after setting the Holy Gifts on the Holy Table, "O God of ineffable and unseen mysteries...," the Prayer after Communion, "We thank you, God the Savior of all things...," the Prayer behind the ambo, "Master almighty, who fashioned creation with wisdom..." All these prayers from the manuscripts of the eighth century are present in the modern ordinance of the Liturgy of the Presanctified Gifts in the same order. At the same time, the Barberini 336, just as the other oldest Euchologia, is almost silent on the actions of the clergy that accompany the prayers. The oldest Euchologia practically lack instructions concerning the service, whereas modern Euchologia and service books cite them in corresponding rubrics. Along with the manuscripts that contain a set of prayers, entirely corresponding to the modern ordinance of the Liturgy, there are some manuscripts among the oldest Euchologia, that have prayers in their ordinances of the Liturgy of the Presanctified Gifts that currently have fallen out of use. (One of the earliest sources of this type is the Ms. Paris. gr. 391 of the Paris National Library dated to the 11th C.). ${ }^{6}$

In 1955 Moraitis made a critical edition of the ordinance of the Liturgy of the Presanctified Gifts on the basis of many Greek manuscripts of the eighth-sixteenth centuries. ${ }^{7}$ These Euchologia have differences not only in the texts of the prayers of the Liturgy of the Presanctified Gifts, but also in the composition of the ordinances of the Liturgy. The subsequent publications, devoted to the Liturgy of the Presanctified Gifts, focused on its initial part, the Vespers, that play a key role in the problem of the origin of the service. In particular, researchers attempted to explain the fact that Psalm 140 occurs twice in the Vespers. Jane-

(5) The "readings" here mean the instruction by the bishops during Great Lent: Н. Д. Успенский, Дитургия Преждеосвященных Даров, Богословские труды 15 (1976) 155.

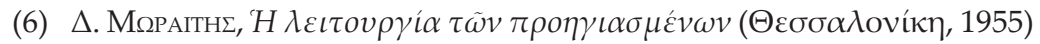
61.

(7) Ibid. 
ras argued that the Vespers of the Liturgy of the Presanctified Gifts has a Constantinopolitan origin and are the result of a combination of the

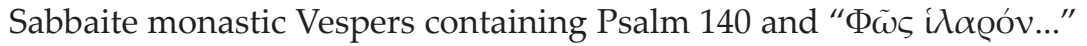
("O gentle Light ...") with the ancient cathedral Constantinopolitan

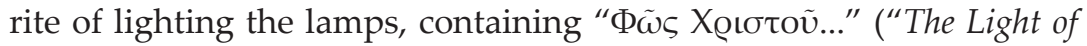

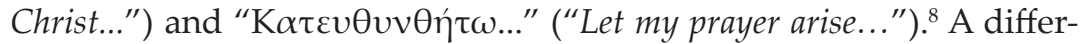
ent view on the origin of the elements of the Vespers was proposed by Engberding who believed that "Let my prayer arise..." was a Prokeimenon after the second Old Testament reading, and "The Light of Christ..." was related to the preparation of the Catechumens for Baptism. ${ }^{9}$ The article of Winkler, who identified an ancient Antiochean core $^{10}$ in the ordinance of the Vespers, had significant impact on the views about the origin of the Vespers in the Liturgy of the Presanctified Gifts. Winkler concluded that the Vespers of the Liturgy of the Presanctified Gifts is the combination of the monastic Sabbaite Vespers (up to "O gentle Light..."), the Antiochean system of Old Testament readings during Lent, and the ancient Antiochean Vespers, in which the repeated rite of light ("The Light of Christ...") and Psalm 140 ("Let my prayer arise...") originated. The study of Arranz ${ }^{11}$ was focused on evidence concerning the Liturgy of the Presanctified Gifts in the Byzantine Euchologia and Typica from the oldest manuscript, and the dissertation of Alexopou$\operatorname{los}^{12}$ summarized the state of current research on the history of the Byzantine Liturgy of the Presanctified Gifts.

The oldest handwritten Slavonic service books represent very valuable historical evidence, substantially supplementing the materials of the oldest Greek Euchologia. The text of the Liturgy of the Presanctified

(8) S. JANERAs, La partie de la liturgie byzantine des Présanctifiés, OCP 30 (1964) 193-222.

(9) H. Engberding, Zur Geschichte der Liturgie der Vorgeewihten Gaben, Ostkirchliche Studen 13 (1964) 310-314.

(10) G. WinkLER, Der geschichtliche Hintergrund der Präsanktifikatenvesper, Oriens Christianus 56 (1972) 184-206.

(11) M. Arranz, La Liturgie des Présanctifiés de l'ancien Euchologe byzantin, OCP 47 (1981) 332-388.

(12) S. Alexopoulos, The Presanctified Liturgy in the Byzantine Rite: a comparative analysis of its origins, evolution, and structural components (Dissertation Submitted to the Graduate School of the University of Notre Dame, Indiana, 2004). Published as S. Alexopoulos, The Presanctified Liturgy in the Byzantine Rite: A Comparative Analysis of its Origins, Evolution, and Structural Components (Leuven: Peeters, 2008) (Liturgia Condenda, 21). 
Gifts is present in most of the Slavonic service books of the thirteenthfifteenth centuries that are listed in the catalogs of modern manuscript collections. Despite the fact that the service books of the thirteenthfifteenth centuries were compiled significantly later than the oldest known Greek Euchologia, some Slavonic manuscripts contain information that sheds light on the earliest stages of development of the Byzantine service of the Presanctified Gifts. These sources primarily include the manuscripts of the Presanctified Liturgy of the Old Russian recension, represented by seventeen manuscripts ${ }^{13}$ (see below p. 12).

A distinctive feature of the Old Russian recension is, primarily, the description of the initial part of the ordinance of the Liturgy of the Presanctified Gifts. Like the earliest Greek Euchologia, the manuscripts of the Old Russian recension of the Liturgy do not contain any initial exclamations, they have no indication of the "beginning according to the custom," and also do not provide the text of the prayers for the Vespers, which are at the beginning of the service of the Liturgy of Presanctified Gifts; the description of the service starts with the moment of the Entrance with the censer. The structure of the text of the ordinance of the Presanctified Liturgy is of the same kind as the structure in the Greek Euchologia of the eighth-eleventh centuries which contain the text of the Liturgy of the Presanctified Gifts at the early stage of its development. ${ }^{14}$ However, the Slavonic service books substantially supplement Greek materials, because, as a rule, they contain more detailed liturgical instructions (rubrics) than corresponding Greek manuscripts. Thus, the Slavonic manuscripts of the Old Russian recension that transmit the

(13) We should note that in: A. С. Слуцкий, Чинопоследование вечерни литургии Преждеосвященных Даров в славянских служебниках XIIXIV вв., in: Славяне и их соседи. Вып. 6 (Москва, 1996), and in: Т. И. АфанАсьевА, А. С. Слуцкий, Чинопоследование литургии Преждеосвященных Даров в двух древнейших болгарских служебниках, Palaeobulgarica (1999) № 3, 88-98, the texts of the Old Russian recension are called "the first" (the initial) Slavonic recension. Only twelve manuscripts are identified in the first study, and only fifteen manuscripts - in the second study. The term "Old Russian recension" was introduced in the article: Т. И. АФАНАсьЕвА, К истории текста Иитургии Преждеосвященных Даров в славянской рукописной традиции XIII - первой половине XIV в., Onыmы по источниковедению. Древнерусская книжность 4 (2001) 34-46.

(14) The periodization of Greek sources was introduced by Moraitis, who identified three stages of development in the Greek handwritten text of the ordinance of the Liturgy of the Presanctified Gifts: MøPaIthг,

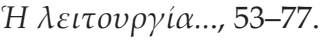


specific features of the liturgical tradition of the Russian Church in the pre-Mongolian period, also constitute a very valuable source for studying the history of the Liturgy of the Presanctified Gifts that reflects a rite of parish worship in Byzantium prior to the catastrophic events of 1204.

The texts of the Old Russian recension have an important feature: these sources belong to the body of liturgical books of the Studite tradition. Various recensions of the rules belonging to the Studite type and their corresponding liturgical service books defined the liturgical tradition of the Russian Church from the end of the 11th until the middle of the 14th century. ${ }^{15}$ In the second half of the fourteenth century the active spreading of the Jerusalem rule, ${ }^{16}$ by this time almost universally accepted in the Orthodox East, started in Russia. Since the fifteenth century, the Jerusalem rule and its related body of liturgical books have become the main regulators of divine service in the Russian Orthodox Church. ${ }^{17}$ Thus, the liturgical texts belonging to the Studite tradition, retain the earlier order of service and hold the most interest for historical and liturgical studies.

In addition to the seventeen manuscripts of the Old Russian recension of the service of the Liturgy of the Presanctified Gifts, the Studite tradition is manifested in the ordinance of the Liturgy contained in six service books of the late thirteenth-mid. fourteenth centuries, which are not related to the Old Russian recension. These six manuscripts, as opposed to the service books of the Old Russian recension, contain an initial exclamation ("Blessed is the kingdom...") $)^{18}$ and the Prayers for the Lighting of the Lamps. As in the case of the Old Russian recension, the feature that allows us to connect the ordinance of the Liturgy of the Presanctified Gifts with the texts of the Studite tradition, is the indica-

(15) А. М. Пентковский, Типикон Алексея Студита в Византии и на Руси (Москва, 2001) 195.

(16) И. Д. МАнсветов, Церковный устав (Типик), его образование и судьба в Греческой и Русской Церкви (Москва, 2001) 269-271. Пентковский, Типикон Алексея Студита..., 216-217.

(17) On the liturgical reforms in the Russian Orthodox Church related to the acceptance of the Jerusalem rule, see: A. М. Пентковский, Литургические реформы в истории Русской церкви и их характерные особенности, Журнал Московской патриархии (2001) № 3, 72-80.

(18) Only the service book III $a 32$ from the Hrvatska akademija znanosti i umjetnosti does not have the initial exclamation in the ordinance of the Liturgy of the Presanctified Gifts, but this is due to the missing pages of the manuscript which contained the beginning of the ordinance. 
tion of performing the Liturgy during Cheese-fare Week, immediately preceding Great Lent. (The Jerusalem rule prescribes the Liturgy of the Presanctified Gifts be performed during Great Lent and the first three days of Holy Week.) Hereafter, the term "manuscripts of the Studite tradition," will normally designate these six manuscripts, listed below on page 13 .

The main subject of this study are twenty-three Slavonic manuscripts of the ordinance of the Liturgy of the Presanctified Gifts dating to the thirteenth-fifteenth centuries that belong to the liturgical tradition preceding the spread of the Jerusalem rule. The liturgical reform in Russia in the fourteenth century, associated, primarily, with Metropolitan Alexey (1354-1378) and Metropolitan Cyprian (1390-1406), ${ }^{19}$ resulted in a general replacement of texts belonging to the Studite tradition with texts of the Liturgy of the Presanctified Gifts with nearly uniform ordinance structure, containing significantly fewer important differences with relation to modern liturgical practices than the earlier manuscripts.

Further development in the ordinance of the Liturgy of the Presanctified Gifts in Russia led to significant discrepancies between the practices of the Russian Orthodox Church and Greek Orthodox Church. According to the opinion reflected in the text of the Russian service book, the chalice contains wine that is not transformed into the Blood of Christ. This theological notion has led to ceremonial differences in Russian and Greek liturgical practices. A detailed historical and theological analysis of the problem about the chalice, which is the main theological question relating to the Liturgy of the Presanctified Gifts (see below p. 47) can be found in a fundamental work by Karabinov. ${ }^{20}$ Further discussion of this theological issue in the articles of Uspensky $^{21}$ and Vanyukov ${ }^{22}$ entirely follows the study of Karabinov.

The manuscript tradition of the Slavonic Liturgy of the Presanctified Gifts until recently did not attract the special attention of researchers. Among many historical and liturgical studies by prominent

(19) ПЕНтковский, Литургические реформы..., 74.

(20) И. КАРАБИНов, Святая чаша на дитургии Преждеосвященных Даров, Христианское чтение (1915) VI, 737-753; VII-VIII, 953-964.

(21) УСпенский, Аитургия Преждеосвященных Даров... Н. Д. УСпенский, Коллизия двух богословий в исправлении русских богослужебных книг в XVII в., Богословские труды (1975) № 13, 148-171.

(22) С. ВАнюков, Чин Дитургии Преждеосвященных Даров (Исследование печатных изданий), Богословский сборник 8 (2001) 269-294. 
Russian liturgical scholars in the late nineteenth - early twentieth century, besides the work of Karabinov, only the article by Muretov ${ }^{23}$ was specifically devoted to the history of the Slavonic Liturgy of the Presanctified Gifts. This article traced the differences between the description of the ordinance of the Liturgy of the Presanctified Gifts in some Medieval Greek and Slavonic manuscripts and the modern ordinance of this service. Some aspects of the service of the Presanctified Liturgy as it is described in the Slavonic service books, were studied in the work of Lisitsin, devoted to the study of the oldest liturgical rules that prescribed the order of divine services in the Russian Church in the initial period of its history. ${ }^{24}$

A systematic study of medieval Slavic manuscripts of the Liturgy of the Presanctified Gifts was begun in the late twentieth century in the works of Slutskij, ${ }^{25}$ and Afanasieva. ${ }^{26}$ The article of Vanyukov contains a collation of texts of the Presanctified Liturgy from old-printed Russian service books and modern editions. ${ }^{27}$ The work by Afanasieva is dedicated to linguistic and textological analysis of Slavic manuscripts containing the ordinance of the Liturgy of the Presanctified Gifts, and takes into account the manuscripts corresponding both to the rules of the Studite type, and to the Jerusalem rule. ${ }^{28}$

This study is limited to the manuscripts belonging to the liturgical tradition prior to the dissemination of the Jerusalem rule. This tradition records the texts of the ordinance at early evolutionary stages of the Liturgy of the Presanctified Gifts. These texts are a valuable source for studying the history of the initial period of both Slavonic and Byzantine divine services. This study examines specific features of the liturgical rite as reflected in the above mentioned sources and focuses on the manuscripts of the Old Russian recension. Along with an analysis

(23) С. Муретов, Особенности литургии Преждеосвященных Даров в древних греческих и славянских памятниках, Московские церковнье ведомости (1896) № 10-12.

(24) М. Аисицин, Первоначальный славяно-русский типикон (историкоархеологическое исследование) (Санкт-Петербург, 1911).

(25) Слуцкий, Чинопоследование вечерни литургии...

(26) Афанасьева, СлуцкиЙ, Чинопоследование литургии..., АфанасьевА, К истории текста Аитургии...

(27) ВАНюКов, Чин Аитургии Преждеосвященных Даров...

(28) Т. И. АФАнасьевА, Славянская литургия Преждеосвященных Даров XII-XV вв.: текстология и язык (Санкт-Петербург, 2004). 
of the ordinance of this, apparently, oldes $\mathrm{t}^{29}$ surviving Slavonic version of the Liturgy of the Presanctified Gifts, Appendix provides a critical edition of the Old Russian recension on the basis of all seventeen manuscripts. ${ }^{30}$ The initial part of the service, the Vespers, is studied in most detail in the following analysis of the structure of the Liturgy of the Presanctified Gifts, which is contained in the first part of this study. The Slavonic manuscripts of the Old Russian recension describe the Vespers significantly better than the Greek manuscripts related to the corresponding stage of evolution of the ordinance of the Liturgy. ${ }^{31} \mathrm{At}$ the same time, the descriptions of the Vespers in the manuscripts of this recension show significant differences. Therefore, the text of all manuscripts of the Vespers is reproduced in full in the critical edition of the Old Russian recension in Appendix.

In addition to the Vespers, the key elements for the historical and liturgical analysis of the ordinance of the Liturgy of the Presanctified Gifts are the ordinance of the Great Entrance, and the description of the actions of clergy associated with Communion. The second and the

(29) Apparently, the text of the ordinance of the Liturgy of the Presanctified Gifts from the West Bulgarian service book Khlud. 117 seems to be close to the protograph, see: Т. И. Афанасьева, Аитургия Преждеосвящценных Даров в славянской рукописной традиции XII-XIV вв. (лингво-текстологический анализ) (Автореферат диссертации, СПбГУ, 2000) 20. The service book Khlud. 117 was written during the reign of King Stefan Uroš II Milutin (12821321) and was used many times in historical and liturgical studies: Муретов, Особенности литургии Преждеосвященных Даров..., № 11, р. 142, 144; № 12, p. 158; АфАнасьевА, Слуцкий, Чинопоследование литургии... However, scholars paid insufficient attention to this service book which is extremely interesting in many respects, being one of the few testimonies of the liturgical traditions of parish service in Western Bulgaria in the thirteenth century (on the Khlud. 117, seе: Б. Н. Флоря, А. А. Турилов, С. А. Иванов, Судъбъ кирилломефодиевской традиции после Кирилла и Мефодия (Санкт-Петербург, 2000) 134; Сводный каталог славяно-русских рукописных книг, хранящихся в России, странах СНГ и Балтии. ХІV век. Вып. 1 (Москва, 2002) 656-661).

(30) The text of the Liturgy of the Presanctified Gifts from the service book Sol. 1016/1125 was chosen as the main text.

(31) Liturgical rubrics in the manuscripts of the Old Russian recension are notably one of the few surviving descriptions of the order for the Vespers of the Presanctified Liturgy during Cheese-fare Week, and supply evidence from the manuscripts of the Typikon of the Great Church - the Church of Hagia Sophia in Constantinople: J. Mateos, Le Typikon de la Grande Église, ms. Saint-croix $n$ 40, $X^{e}$ siècle (Roma, 1963) (Orientalia Christiana Analecta, 166) 6-8; А. А. Дмитриввский, Древнейщие патриаршие Типиконы (Киев, 1907) 327-330. 
third parts of this study are dedicated to these elements of the ordinance of the Liturgy of the Presanctified Gifts.

The list of seventeen Slavonic manuscripts of the Liturgy of the Presanctified Gifts which form the subject of this study, is cited below. The refinement of the dating of manuscripts in this list primarily follows the recent fundamental work by Zheltov, who investigated the manuscript tradition of the Slavonic Liturgy of John Chrysostom. ${ }^{32}$

\section{Manuscripts of the Old Russian Recension}

1. Syn. 604, State Museum of History, early 13th C., ${ }^{33}$ SK 11-13 № $167 .^{34}$

2. Sof. 519, National Library of Russia, early 13th C., SK 11-13 №313.

3. Sof. 518, National Library of Russia, late 13th - early 14th C., ${ }^{35}$ SK 11-13 № 312.

4. YaMZ 15472, Yaroslavl Reserve-Museum, 1328-1336,, ,6 $^{36}$ № 469.

5. Sol. 1016/1125, National Library of Russia, mid. 14th - 15th C., ${ }^{37}$ SK 11-13 № 310.

6. O.p. I.5, National Library of Russia, first half - mid. 14th C., ${ }^{38}$ PS № 1087.

7. Sof. 521, National Library of Russia, second half of the 14th C., ${ }^{39}$ PS № 1237.

(32) М. ЖЕлтов, Чин Божественной дитургии в древнейших (XIXIV вв.) славянских Служебниках, Богословские труды 41 (2007) 272-359.

(33) The dating is clarified on the basis of: О. С. ПоповА, Миниатюры Хутынского Служебника раннего XIII в., in: Древнерусское искусство: Русь. Византия. Балканы. ХІІІ в. (Санкт-Петербург, 1997) 274-289.

(34) For each manuscript we give the reference number, name of collection, date and, whenever possible, the number according to the catalogue SK for the 11th-13th С. (Сводный каталог славяно-русских рукописных книг, хранящиихся в СССР. XI-XIII вв. (Москва, 1984) or (in case of absence in the SK) according to the PS (Предварительный список славяно-русских рукописей, XI-XIV веков, хранящихся в СССР, in: Археографический ежегодник за 1965 г. (Москва, 1966) 177-309).

(35) The dating is clarified by Turilov (see: ЖЕлтов, Чин Божественной литургии..., 281).

(36) The dating is clarified by Turilov (see: Ibid., 282).

(37) The dating is clarified by Turilov (see: Ibid.).

(38) The dating is clarified by Turilov (see: Ibid., 284).

(39) Possibly the turn of the 14 th-15th C. The dating is clarified by Turilov (see: Ibid., 282). 
8. Syn. 892, State Museum of History, second half of the 14th C., PS № 1232.

9. Rum. 399, Russian State Library, second half of the 14th C., PS № 751.

10. Rogozh. kladb. 566, Russian State Library, 14th C., PS № 866.

11. O.p. I.4, National Library of Russia, 14th C., PS № 1086.

12. Sof. 526, National Library of Russia, 14th C., PS № 1239.

13. Slav. 1, N.Y. Public Library, second half - third quarter of the 14th $\mathrm{C}^{40}$

14. Syn. 598, State Museum of History, late 14th C., PS №868.

15. Syn. typ. 40, Russian State Archives of Ancient Acts, 14 - early 15th C., PS № 1481.

16. Sof. 525, National Library of Russia, late $14^{\text {th }}-$ early 15 th C., ${ }^{41}$ SK 11-13 № 314.

17. Syn. typ. 43, Russian State Archives of Ancient Acts, 15th C. ${ }^{42}$

\section{Manuscripts of the Studite Recension}

1. Khlud. 117, State Museum of History, 13th C.43

2. Q.p. I.68, National Library of Russia, second half of the 13th C., SK № 397.

3. Q.p. I.67, National Library of Russia, ca. 1316, ${ }^{44}$ SK № 479.

4. Uvar. 46, State Museum of History, first half (early) 14th C. ${ }^{45}$

5. III a 32, Hrvatska akademija znanosti i umjetnosti, first half of the 14th C. ${ }^{46}$

6. Uvar. 574, State Museum of History, mid. 14th C. ${ }^{47}$

(40) The dating is clarified on the basis of Э. С. СмирновА, Русский дицевой Служебник в Нью-Йорке, Хризограф 2 (2005) 54-73.

(41) The dating is clarified on the basis of SK 14: Сводньй каталог славяно-русских рукописных книг, хранящзихся в России, странах СНГ и Балтии. XIV век. Вып. 1 (Москва, 2002) 579.

(42) The dating is clarified by Turilov (see: Желтов, Чин Божественной литургии..., 284).

(43) SK 14, p. 591.

(44) The dating is clarified on the basis of SK 14, p. 591.

(45) The dating is clarified by Turilov (see: Слуцкий, Чинопоследование вечерни литургии..., 131).

(46) V. Mošın, Cirilski rukopisi JAZU, t. 1 (Zagreb, 1952).

(47) The dating is clarified by Turilov (see: Слуцкий, Чинопоследование вечерни литургии..., 131). 